\title{
Final Project and Minithesis on Economics Topics: Problems and Solution
}

\author{
Ni Made Ary Widiastini ${ }^{1}$, Nyoman Dini Andiani², Made Aristia Prayudi ${ }^{3}$
}

1,2,3 Universitas Pendidikan Ganesha

\section{A R T I C L E I N F 0}

Article history:

Received 20

Desember 2017

Received in revised form

7 Januari 2018

Accepted 15

Februari 2018

Available online 20

Februari 2018

Keywords:

Final Project,

Minithesis, Diploma,

Sarjana, Economics

\begin{abstract}
A B S T R A C T
This paper tries to describe problems faced by students in general in writing final project or minithesis on Economics topics. As the last requirement every student at the Sarjana and Diploma levels, final project or minithesis is often a new and difficult problem faced by the students as they enter the last semester. In some cases, the students besides being late to graduate also drop out because they do not finish the final project or minithesis at the end of the study program. One of the factors that cause this is the studens' failure to understand what to be chosen as a problem, to formulate the problem, or to find an appropriate title for the problem, so that the solution to the problem has been formulated. In this paper is described the technique to understand something which is appropriate to be made a title for a final project or minithesis, then how to formulate problems, to select a method of study which is suitable for the problem investigated, the data collection technique and data analysis. Through this paper it is expected that the students at the Sarjana and Diploma levels can understand how to write a final project or thesis in a simple away.
\end{abstract}

\section{Introduction}

Final project and minithesis are very common and known by people in general, especially students in the study programs at Diploma and Sarjana levels. Listening to these words, the studen often feel anxious and even tend to be afraid before doing the final project or thesis. Final project or minithesis is a scientific writing written by every student in every study program based on experience, observation and research on a problem which is done carefully under the guidance of advisers. In this case, final project and minithesis are part of requirements for graduation, the terms and condition about the standard or the format are determined by the university.

In practice, almost all students face difficulty and find themselves under stress when writing a final project or minithesis. As what is stated by Aswati (2014) there are some factors that cause students to suffer from stress when writing final project and minithesis, some of them are the failure to understand the way how to find a topic of research, the difficulty in searching literature, lack of understanding about data analysis technique, lack of understanding of the technique of writing final project or thesis, etc. In this case, students during the lectures do not pay enough attention to theories and practices explained by the lecturers in the class room tend to find it difficult to writing final project or minithesis and the lecturers often assign to write papers as a group work in which not all students want to write good papers. Besides plagiarizing most of the time, the students are lazy and let other members complete the paper, so that they are weak at writing. The ability to find a topic and then elaborate it into some formulations of problems which is then followed by describing the results of analysis of the problem investigated can actually can be trained every time they are assigned to write papers, which is the task every lecturer. This is obviously very useful for preparing the students to write their final project or minithesis well, so that they are able to graduate on time. 
The limitation in students' activities in reporting the result of observation in the form of paper can have an implication on the weakness in their ability in selecting a topic for final project or minithesis. As set up in Pedoman Penulisan Tugas Akhir dan Skripsi Universitas Peddikan Ganesha (2017) the identification of problems for final project and minithesis is as follows:

Identifikasi masalah untuk Tugas Akhir dapat diangkat dari hasil praktik (praktik kerja lapangan, praktik pengalaman lapangan, dan sejenisnya) yang boleh dilakukan bagi mahasiswa program Diploma. Skripsi dapat didasarkan atas informasi dari koran, majalah, buku jurnal, laporan penelitian, seminar, atau keadaan lapangan (Undiksha, 2016).

The problems for final project can be identified from the result of practices (field work, field experience practices, and the like ) which can be done by students of Diploma program. Minithesis can be based on information from daily newspapers, magazines, journals, research reports seminars, or field conditions (Undiksha 2016).

Based on the quotation above, it is very important for every Diploma student to understand practical activities done during the courses, observations in industries for certain courses, and when they are doing on job training an industry. While students at Sarjana level should be diligent in looking for information both in printed and electronic media, in addition to making observation or certain courses that make them able to sharpen their sensitivity in selecting a topic for minithesis.

The routine students do in writing about various types of problems both during the courses and in the field in the form of scientific papers have an implication to their ability in completing final project and minithesis. However, in the application, data analysis also becomes an important problem faced by every students in processing Data that they find while they use quantitative or qualitative approach in analyzing the Data that they found. Thus, an understanding of the too a processes will certainly become the important focus of every lecturer, especially the one who teaches scientific writing or research methodology to give some understanding of the too types of approach to the students.This is stated by Iswahyudi (2015) as follows.

Kendala yang dialami mahasiswa masih menyeluruh paling banyak muncul adalah mahasiswa masih kesulitan mencari dan menemukan permasalahan penelitian yang akan ditulis. Setelah permasalahan ditemukan mereka kesulitan menentukan judul penelitian baik Dari segi bahasa maupun substansi yang berkaitan Dengan metodologi penelitian apakah kualitatif atau kuantitatif. Mahasiswa masih menemukan kesulitan teknis penulisan proposal maupun skripsi, kesulitan metodologi terutama pada analisis data. Dari kendala metodologi itu, akhirnya banyak mahasiswa yang menggunakan metode penelitian dan analisis meniru metode dan analisis hasil penelitian terdahulu seperti skripsi yang sudah ada di perpustakaan (Iswahyudi, 2015: 11).

Most students face the problems in searching an finding problems of the study that will be done. After the problem is found they have difficulty in determining the title of the research both in terms of language and substance related to the method of research whether qualitative or quantitative. The students still face technical difficulty in writing proposal and thesis, Difficulty in methodology especially in data analysis. From the methodological problem, most students use a method of research and analysis by imitating a method and an analysis of research in a previous minithesis that can be found in the library (Iswahyudi, 2015: 11).

Final project or thesis in practice often becomes a difficult problem for some students.After knowing problems faced by the students both at Diploma and Sarjana levels, in this paper the technique of writing final project or minithesis in a simple away will be discussed, that is, by writing a background of the study, breaking down the title into some formulations of problems, understanding concepts and theories used in the study, research method, Discussing the result of the data analysis, writing conclusion of each discussion, and writing suggestions based on problem solving done.

\section{Method}

Research method is a systematical effort to solve problems made in the research to obtain an appropriate answer to the problem according to the expectation about the problems enumerated in detail in the problem formulation. There are two research methods, i.e., quantitative and qualitative methods. Quantitative research method is one of research types which is systematical, planned, defined as the kind of research which demands extensively the use of numbers, figures, tables, graphs and the like starting from data collection and ending in discussion as stated by Sugiyono (2012) that quantitative method can be defined as research method based on positivist philosophy used to study a sample or a certain population. Quantitative research is also a study positioned as value free, which in this case is very 
rigid in applying the principle of objectivity obtained through the use of instruments that have been tested in terms of validity and reliability (Danim, 2003).

Qualitative research is a kind of research which stresses more the element of understanding of a problem in depth.In its practice, this research tends to use in-depth analysis, by investigating a problem case by case since this kind of research is based on the belief that every problem has different characteristics. Qualitative method is also called interpretative method since the researcher has to interpret his or her result based on the approach and theory he or she selected. Bogdan ani ${ }^{*}{ }_{18}$ " or in Moleong (2004:3) explain that qualitative method is a research procedure which produces 18 stive data in the form of words or speeches from people and behaviour observed. Miles and Huberman in Sudikin (2002:2) explain that qualitative method tries to reveal some uniquenesses found in individuals, group, society, and/or organization in daily life in detail, comperhensively, and is not value free, i.e., can be accounted $\backslash$ scientifically according to rules in life that prevail.

Table 1 below explains the differences between researches which use quantitative approach and those which use qualitative approach. Hamidi (2004) enumerates twelve Differences between quantitative and qualitative approaches as shown in table 1.

Table 1 Differences between Quantitative and Qualitative Researches

\begin{tabular}{|c|c|c|c|}
\hline No & $\begin{array}{l}\text { Type } \\
\text { Difference }\end{array}$ & Quantitative & Qualitative \\
\hline 1 & Perspective & $\begin{array}{l}\text { Quantitative research tends to use } \\
\text { atic approach }\end{array}$ & $\begin{array}{l}\text { Qualitative research tends to } \\
\text { used emic approach. }\end{array}$ \\
\hline 2 & $\begin{array}{l}\text { Concept and } \\
\text { Theory }\end{array}$ & $\begin{array}{l}\text { Quantitative research departs from } \\
\text { concept (variable) found in the theory } \\
\text { selected by the researcher whose data } \\
\text { are then found, through questionnaire } \\
\text { to measure the variables. }\end{array}$ & $\begin{array}{l}\text { Quantitative research Departs } \\
\text { from concept, theory or the } \\
\text { retest of the story, while } \\
\text { qualitative research develops, } \\
\text { creates, finds concept or theory. }\end{array}$ \\
\hline 3 & Hypothesis & $\begin{array}{l}\text { Quantitative research formulates } \\
\text { hypothesis since the beginning, which } \\
\text { originate from the relevant theory } \\
\text { selected. }\end{array}$ & $\begin{array}{l}\text { Qualitative research can used } \\
\text { hypothesis but usually without } \\
\text { hypothesis. }\end{array}$ \\
\hline 4 & $\begin{array}{l}\text { Data collection } \\
\text { technique }\end{array}$ & $\begin{array}{l}\text { Quantitative research prioritizes the } \\
\text { use of questionnaire. }\end{array}$ & $\begin{array}{l}\text { Qualitative research prioritizes } \\
\text { the use of interview and } \\
\text { observation. }\end{array}$ \\
\hline 5 & $\begin{array}{l}\text { Problem and } \\
\text { aim of research }\end{array}$ & $\begin{array}{l}\text { Quantitative research ask questions } \\
\text { or wants to find out the extent of } \\
\text { effect, the correlation or association } \\
\text { among variables or degrees of a } \\
\text { variable by using measurement. }\end{array}$ & $\begin{array}{l}\text { Qualitative research ask } \\
\text { questions or wants to find out } \\
\text { about meaning (in the form of } \\
\text { concepts) that exists behind the } \\
\text { detailed story given by the } \\
\text { respondents with the social } \\
\text { background being studied. }\end{array}$ \\
\hline 6 & $\begin{array}{l}\text { Number } \\
\text { Respondent }\end{array}$ & $\begin{array}{l}\text { In quantitative approach the size } \\
\text { (extent, number) of the sample is } \\
\text { representative and is obtained by } \\
\text { using a formula, percentage or table- } \\
\text { population-sample and has been } \\
\text { determined before data collection. }\end{array}$ & $\begin{array}{l}\text { In qualitative research the } \\
\text { number of respondents is } \\
\text { known when data collection is } \\
\text { saturated. Data collection is } \\
\text { started from interviewing prior } \\
\text { informants or key informants } \\
\text { and stopped with the } \mathrm{n}^{\text {th }} \\
\text { respondent when the sources } \\
\text { persons do not give new } \\
\text { information anymore or is } \\
\text { saturated (snow ball). }\end{array}$ \\
\hline 7 & $\begin{array}{l}\text { Conclusion } \\
\text { Drawing }\end{array}$ & $\begin{array}{l}\text { Quantitative research follows the } \\
\text { process deductively, i.e., from the } \\
\text { determination of variable (concept), } \\
\text { followed by data collection and } \\
\text { conclusion. }\end{array}$ & $\begin{array}{l}\text { Qualitative research follows the } \\
\text { processes inductively, i.e., the } \\
\text { process is started from the } \\
\text { effort to obtain detailed data } \\
\text { (respondent's autobiography, }\end{array}$ \\
\hline
\end{tabular}




\begin{tabular}{|c|c|c|c|}
\hline No & $\begin{array}{l}\text { Type } \\
\text { Difference }\end{array}$ & Quantitative & Qualitative \\
\hline & & & $\begin{array}{l}\text { life story, life cycle, related to } \\
\text { the topic or problem being } \\
\text { studied), .without being } \\
\text { evaluated and interpreted, and } \\
\text { then are categorized, } \\
\text { abstracted and the theme, } \\
\text { concepts or theories are found } \\
\text { as findings. }\end{array}$ \\
\hline 8 & $\begin{array}{l}\text { Data } \\
\text { Presentation }\end{array}$ & $\begin{array}{l}\text { Quantitative research is in the form of } \\
\text { numbers or tables. }\end{array}$ & $\begin{array}{l}\text { The data of qualitative research } \\
\text { are presented in the form of } \\
\text { detailed story according to the } \\
\text { language and the perspective of } \\
\text { the respondent. }\end{array}$ \\
\hline 9 & $\begin{array}{l}\text { Operational } \\
\text { Definition }\end{array}$ & $\begin{array}{l}\text { Quantitative research uses } \\
\text { operational definition in which the } \\
\text { researcher has determined the types } \\
\text { and number of indicators, which } \\
\text { mean he or she has limited the } \\
\text { subjects of research in expressing } \\
\text { opinions, experiences or perspective. }\end{array}$ & $\begin{array}{l}\text { Qualitative research does not } \\
\text { need to use operational } \\
\text { Definition since it will not } \\
\text { measure variables (operational } \\
\text { definition) is a guideline on how } \\
\text { to measure a variable. }\end{array}$ \\
\hline 10 & Data analysis & $\begin{array}{l}\text { Quantitative research is done at the } \\
\text { end of data collection by using } \\
\text { statistical computation. }\end{array}$ & $\begin{array}{l}\text { The data of qualitative research } \\
\text { are analyzed since the arrival at } \\
\text { the location by collecting data } \\
\text { by means of "installing or } \\
\text { saving" information, reducing, } \\
\text { grouping, etc until finishing it } \\
\text { with an interpretation. }\end{array}$ \\
\hline 11 & $\begin{array}{l}\text { Research } \\
\text { instrument }\end{array}$ & $\begin{array}{l}\text { The instrument for quantitative } \\
\text { approach is questionnaire. }\end{array}$ & $\begin{array}{l}\text { Qualitative research uses the } \\
\text { researcher as instrument. Since } \\
\text { researcher as human can adopt } \\
\text { to the respondents and their } \\
\text { activities. This is very impo } 20 \\
\text { to be done in quali1 } \\
\text { research in order the } \\
\text { respondent as source of the } \\
\text { data become more open in } \\
\text { giving information. }\end{array}$ \\
\hline 12 & Conclusion & $\begin{array}{l}\text { The interpretation of data in } \\
\text { qualitative research is done through } \\
\text { checking an agreement with the } \\
\text { subject of research, since it is the who } \\
\text { a more appropriate to give } \\
\text { explanations about data or } \\
\text { information that has been } \\
\text { revealed.The researcher gives an } \\
\text { explanation of the interpretation } \\
\text { made, why certain concept are } \\
\text { selected. }\end{array}$ & $\begin{array}{llr}\text { Quantitative research } & \text { is } \\
\text { "completely" done by the } \\
\text { researcher, based } & \text { on } \\
\text { computational result } & \text { or } \\
\text { statistical analysis. } & \end{array}$ \\
\hline
\end{tabular}

Source: Hamidi (2004: 14-16)

Based on the explanation about the Differences between quantitative and qualitative researches explained by Hamidi (2004: 14-16), it can be understood that the Differences start from the beginning in selecting a topic, in which the researcher has to select an approach according to his or her ability and need .Then, it is followed by giving an example of data collection method through questionnaire according to the topic selected in table 2, i.e., "Analysis of Stress in Production Division Workers." 
Table 2. Example of the Process of Writing Questionnaire for Measuring the Stress Level in Worker's According to its Dimensions

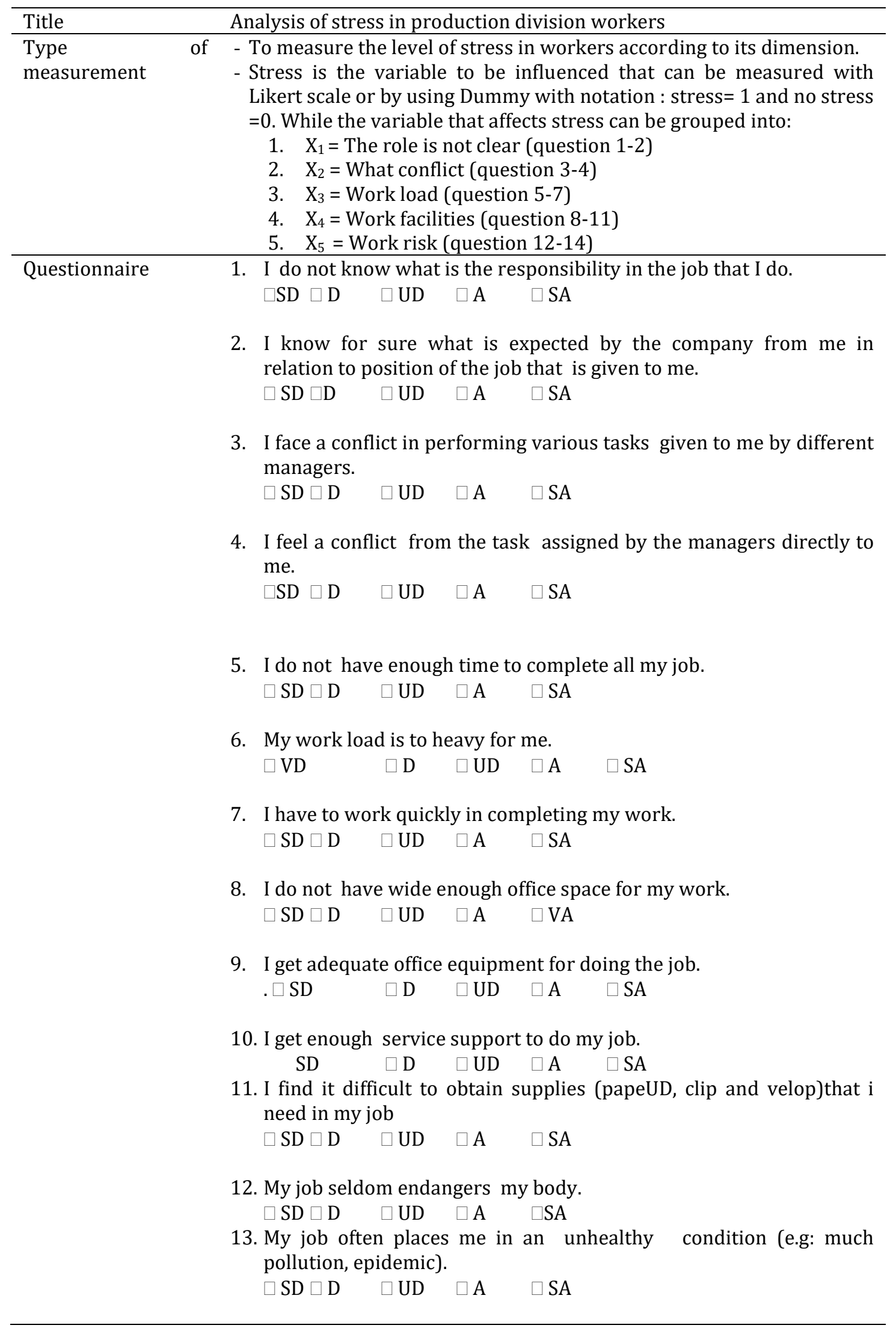




\begin{tabular}{ll}
\hline Title & Analysis of stress in production division workers \\
\hline 14. Serious work accident often occurs in my job. \\
$\square \mathrm{SD} \square \mathrm{D} \quad \square \mathrm{UD} \quad \square \mathrm{A} \quad \square \mathrm{SA}$ \\
\\
Note: \\
$\mathrm{SD}=$ strongly disagree \\
$\mathrm{D}=$ disagree \\
$\mathrm{UD}=$ undecided \\
$\mathrm{A}=$ agree \\
$\mathrm{SA}=$ strongly agree
\end{tabular}

Source: Supriyanto and Machfudz (2010)

Table 3. Example of Interview Guide For the Topic "Analysis of Stress in Production Division workers"

\begin{tabular}{|c|c|c|}
\hline No & Problem formulation & Interview Guide \\
\hline 1 & $\begin{array}{l}\text { To what extent does change of } \\
\text { management effect } \begin{array}{l}\text { worker's } \\
\text { productivity }\end{array}\end{array}$ & $\begin{array}{l}\text { 1. Why management change was done in } \\
\text { production? } \\
\text { 2. How does the new manager interact with } \\
\text { workers? } \\
\text { 3. Is there any obstacle or problem resulted } \\
\text { from the change of management? }\end{array}$ \\
\hline 2 & 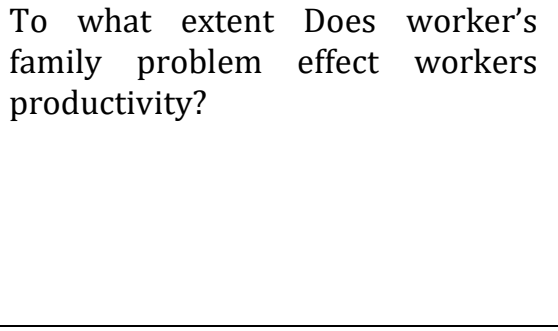 & $\begin{array}{l}\text { 1. Is there any correlation between } \\
\text { worker's family problem and worker's } \\
\text { productivity? } \\
\text { 2. Why can family problem affect worker's } \\
\text { productivity? } \\
\text { 3. What is the effect of the correlation } \\
\text { between family problem and worker's } \\
\text { productivity? }\end{array}$ \\
\hline 3 & $\begin{array}{l}\text { To what extent does the lighting in } \\
\text { the work station affects worker's } \\
\text { productivity? }\end{array}$ & $\begin{array}{l}\text { 1. Why does the lighting in work station } \\
\text { affect worker's productivity? } \\
\text { 2. What type of lighting of work station } \\
\text { which can affect workers productivity? }\end{array}$ \\
\hline 4 & $\begin{array}{l}\text { To what extent does production } \\
\text { target pressure affect worker's } \\
\text { productivity? }\end{array}$ & $\begin{array}{l}\text { 1. Why does production target become an } \\
\text { important thing in the business? } \\
\text { 2. Is there any effect of production target } \\
\text { pressure on worker's productivity? }\end{array}$ \\
\hline 5 & $\begin{array}{l}\text { To what extent does } \\
\begin{array}{l}\text { regulation } \\
\text { rigidity affect } \\
\text { productivity? }\end{array}\end{array}$ & $\begin{array}{l}\text { 1. Why is regulation in work important to } \\
\text { be applied to the workers? } \\
\text { 2. Is there any effect of regulation rigidity } \\
\text { on workers productivity? }\end{array}$ \\
\hline
\end{tabular}

Table 4 The Example of Variables and Operational Definitions

\begin{tabular}{ll}
\hline Variable & Operational Definition \\
\hline Age & $\begin{array}{l}\text { Respondent's age at the time the information is asked from him or } \\
\text { her. }\end{array}$ \\
Stress & $\begin{array}{l}\text { Response from the condition that occurs when an individual is } \\
\text { suffering from stress because of his or her inability to adapt himself } \\
\text { or herself to the demand made on him or her. }\end{array}$ \\
The number of activities that have to be completed by a person or a \\
group for a work unit in a certain period. Work load measurement is \\
defined as a technique for obtaining information about work \\
efficiency and effectiveness of a person or a group or a work unit.
\end{tabular}

While in quantitative research questionnaire is an important instrument for collecting data, in qualitative research interview guide tends to be used for data collection. The title "Analysis of stress in 
production division workers" can also be provided with its interview guide based on each problem formulation.

Through the two examples of the instrument for Data collection in tables 8 and 9 above, both questionnaire and interview guide, it can be understood that determining research data variable is the important first step in writing research instrument. By understanding the variables to be found, the researches can easily write things that have to be found in the field.

\section{Result}

The final project or minithesis is actually aimed at preparing each student to write a scientific paper according to the field of the study that they undertake. Hence, in choosing a problem the students have to base it on the discipline that they study so that in writing final project and minithesis they understand how to solve problems to be investigated.In this context, knowledge and science that they got during the courses in the form of theories and practices can be applied in writing final project and minithesis by using the approaches that they got during the courses. Various things that they got through observations both directly and indirectly can be used as the background of study based on rational thinking, in which differences between reality and ideal condition will make a student think to understand the problems more deeply. In this case, the way how to look at the phenomenon is based on the cognitive ability of each student which is formed based on knowledge and experience that the students received during the courses.

Understanding the should (theory) and reality (empiric) is the beginning in designing a scientific paper for the students. Grant and Osanloo (2014) state that the importance of theory -driven thinking and acting is emphasized in relation to the selection of topic, the development of research questions, the conceptualization of the literature review, the design approach, and the analysis plan for the project, including minithesis. And, as what is stated by Supriyanto and Machfudz (2010: 46) the background of the study is the rationale for the problem to be investigated, and a researcher has to be able to understand the contradiction between the real condition and the ideal condition (theory). The examples of research topic based on the gap between theory and empiric are presented in table 5 as follows.

Table 5. Example of Research Topic

\begin{tabular}{ll}
\hline Research Topic & An analysis of stress in production division workers \\
\hline The Should (Theory) & $\begin{array}{l}\text { Production division workers, with an increase in their pay will work } \\
\text { over time with an increase in their productivity } \\
\text { Reality/real (empiric) } \\
\text { Many production division workers have lower productivity (20-40) } \\
\text { from previous productivity }\end{array}$ \\
\hline ource: Supriyanto and Machfudz (2010: 47).
\end{tabular}

As Uhlig (2012) state, there are three helpful; source for finding a general subject are: (1) draw upon your former experience, (2) peruse journal and new database in areas interest to you, because journal often include section on recent developments and new cases that can provide a good starting point for choosing a subject area, (3) talk with practitioners in your area of interest. The occurrence of something (reality) which deviates or does not conform to the theory provides an opportunity to investigate and to select it as a topic of research. In this case, through an understanding of concept and theories we can predict a cause of the occurrence of the mismatch between theory and empiric, so that there is a need to investigate the cause of the phenomenon. Table 6 below is about the prediction of the causing factor of the mismatch between theory and empiric.

Table 6 Example of Prediction about Causing Factor

\begin{tabular}{ll}
\hline Research Topic & AnAnalysis of stress in production division workers \\
\hline The Should & $\begin{array}{l}\text { Production division workers with an increase in their pay will work over } \\
\text { time with and increase in their productivity. }\end{array}$ \\
Reality & $\begin{array}{l}\text { Many production division workers have lower productivity (20-40) from } \\
\text { previous productivity } \\
\text { For example there is the change of management, worker's family } \\
\text { problem, lighting in work stations which does not support productivity, }\end{array}$ \\
\hline
\end{tabular}


target pressure, rigid regulation, etc. This factors can be ust 24 variables that will be studied so that the development of the variables by the researchers has started since the writing of the background and/formulation of problems. If this is done, the researcher can be said to be clear enough in giving information to the reader.

Cuervo, et al. (2007) state that the study of entrepreneur as individuals analyses the variables that explain their appearance, such as personal characteristics, the psychological profile (the need for achievement, the capacity to control, tolerance of ambiguity and a tendency to take risks) or non-psychological variables (education, experience, networks, the family, etc).

Source: Supriyanto and Machfudz (2010: 51)

Understanding the mismatch between theory an empiric can direct us to the reason why the phenomenon occurs, so that finally it can make a researcher able to predict the causing factor of the gap between theory and empiric. As what is stated by Krisyantono (2006: 3) the objective of a study is to find a relation between phenomena through an accurate and systematical analysis of the empirical data. Parallel to this idea, Prajarto (2010: 1) explains that in research activities the researcher tries to express a problem, to find the basis for understanding of the problem, and to determine and appropriate way to solve the problem. Hence, the background of fact or ideas that are relevant to the problem studied is described in the introduction as the point of departure of research problem formulation. Similarly,the urgency of research is directed to answer why the research is important to be conducted.

\section{Formulation of Problem: Brief and Clear Description of Research Problem in the Form of Question}

Research problem is an elaboration of problem identification which is at the same time also the limitation of the problem studied. In this case, the limitation of the problem is needed for the study to be focused on things related to the topic of the problem, limitation of the problem is made in order the research is not bias or becomes very broad extending beyond the topic. Problem formulation states in detail the things whose solution has to be found in the form of questions. In formulating a problem the question is written completely in detail about the scope of the problem to be studied based on problem identification and problem limitation. As what is stated by Nasution (2009:1) in elaborating problem formulation the interrogative sentences have to be clear and brief and contain concepts used as an effort to focus on the research question.

Supriyanto and Machfudz (2010: 52) explain that the basis of problem formulation is backgrc the researcher has to express factors which cause the problems to be studied. Table 7 below is 25 example of problem formulation elaboration.

Table 7. Example of Research Problem Formulation

\begin{tabular}{ll}
\hline Research Topic & Analysis of stress in production division workers \\
\hline The Should & $\begin{array}{l}\text { Production division worker with an increase in their pay will work over } \\
\text { time with an increase in their productivity. }\end{array}$ \\
\hline Reality & Many production division workers have lower productivity (20-40) from \\
& previous productivity \\
\hline Causing Factor & For example there is the change of management, worker's family \\
problem, lighting in work stations which does not support productivity, \\
target pressure, rigid regulation, etc. This factors can be used as \\
variables that will be studied so that the development of the variables by \\
the researchers has started since the writing of the background \\
and/formulation of problems. If this is done, the researcher can be said \\
to be clear enough in giving information to the reader.
\end{tabular}




\begin{tabular}{c}
\hline productivity? \\
5. $\quad$ To what extent does the rigidity of regulation affect the workers \\
productivity?
\end{tabular}

Source: Supriyanto and Machfudz (2010: 51)

After the researcher writes problem formulation, the next step is to write research aims according to problem formulation. In this case the aim of the study is a brief statement which contains a verb the result of which can be measured and contains results that are expected to be achieved in the study. Table 7 below is an example of the elaboration of the aim of research based on problem formulation.

Table 8. Example of Research Aim

\begin{tabular}{|c|c|}
\hline Research Topic & Analysis of stress in production Division workers \\
\hline The should & $\begin{array}{l}\text { Production division worker with an increase in their pay will } \\
\text { work over time with an increase in their productivity }\end{array}$ \\
\hline Reality & $\begin{array}{l}\text { Many production division workers have lower productivity (20- } \\
\text { 40) from previous productivity }\end{array}$ \\
\hline Causing Factors & $\begin{array}{l}\text { For example there is the change of management, worker's family } \\
\text { problem, lighting in work stations which does not support } \\
\text { productivity, target pressure, rigid regulation, etc. This factors can } \\
\text { be used as variables that will be studied so that the development } \\
\text { of the variables by the researchers has started since the writing of } \\
\text { the background and/formulation of problems. If this is done, the } \\
\text { researcher can be said to be clear enough in giving information to } \\
\text { the reader. }\end{array}$ \\
\hline $\begin{array}{l}\text { Research Problem } \\
\text { Formulation }\end{array}$ & $\begin{array}{l}\text { 1.To what extent does change of management affect worker's } \\
\text { productivity? } \\
\text { 2.To what extent does worker's family problem affect his or her } \\
\text { productivity? } \\
\text { 2. To what extent lighting in the work station affect the worker's } \\
\text { productivity? } \\
\text { 3. To what extent does production target pressure affect worker's } \\
\text { productivity? } \\
\text { 5. To what extent does the rigidity of regulation affect the } \\
\text { worker's productivity? }\end{array}$ \\
\hline Research Aim & $\begin{array}{l}\text { 1. To find out and describe the extent of the effect of change of } \\
\text { management on workers productivity } \\
\text { 2. To find out the extent of the effect of worker's family problem } \\
\text { on the worker's productivity. } \\
\text { 3. To find out and describe the extent of the effect of the lighting } \\
\text { of work station on worker's productivity. } \\
\text { 4. To find out and describe the extent of production of target } \\
\text { pressure on worker's productivity. } \\
\text { 5. To find out and describe the extent of the effect of the rigidity } \\
\text { of regulation on worker's productivity. }\end{array}$ \\
\hline
\end{tabular}

Source: Supriyanto and Machfudz (2010: 59)

Base on table 8 above it can be seen that the aims of research are written based on research questions expressed in research problem formulations. The aims of research are also written with the purpose to find relation or to compare too variables.In table 5 below it can be seen the relation of variables that are written in detail in problem formulations and research aims.

Table 9. Example of Research Variable

\begin{tabular}{ll}
\hline \multicolumn{1}{c}{ Problem Formulation } & \multicolumn{2}{c}{ Research Aims } \\
\hline $\begin{array}{l}\text { 1.To what extent does change of management } \\
\text { affect worker's productivity? }\end{array}$ & $\begin{array}{l}\text { To find out and describe the extent of the } \\
\text { effect of change of management on } \\
\text { 2. To what extent does worker's family }\end{array}$ \\
\hline
\end{tabular}


problem affect his or her productivity?

3. To what extent lighting in the work station affect the worker's productivity?

4. To what extent does production target pressure affect worker's productivity?

5. To what extent does the rigidity of regulation affect the workers productivity?
2. To find out the extent of the effect of worker's family problem on the worker's productivity.

3. To find out and describe the extent of the effect of the lighting of work station on worker's productivity.

4. To find out and describe the extent of production target pressure on worker's productivity.

5. To find out and describe the extent of the effect of the rigidity of regulation on worker's productivity.

Source: Supriyanto and Machfudz (2010: 59)

\section{A Theory: A Series of Assumptions, Concepts and Propositions for Explaining a Social Phenomenon Systematically by Formulating Inter-conceptual Relations}

Ary, Jacobs, Razavieh (2000: 36) and Kerlinger (1978) explain that scientific theory is a set of concepts which are interrelated or a set of constructs (concepts), definitions and propositions which function for looking at the phenomenon systematically, through specifying inter--variable relations, so that it can be useful for explaining and predicting a phenomenon. In practice, many researchers face difficulty in understanding theories which are suitable for the topic of the problems studied. Theory in its application is used as the basis or foundation of a research, so that in its process, the theory selected has to be relevant to the topic of the research. Hence, theory will be easy to understand if the researcher really understands the problem studied as pointed out by Mark in Sugiono (2012) that there are three kinds of theory, i,e., (1) deductive theory which give an explanation starting from a prediction or certain speculative thought toward the data to be explained; (2) inductive theory gives explanation from the data toward theory

Table 10. Example of Theoretical Foundation

\begin{tabular}{|c|c|}
\hline Research Topic & Analysis of stress in proDuction Division workers \\
\hline $\begin{array}{l}\text { Research Problem } \\
\text { Formulation }\end{array}$ & $\begin{array}{l}\text { 1. To what extent does change of management affect worker's } \\
\text { productivity? } \\
\text { 2. To what extent does worker's family problem affect his or her } \\
\text { productivity? } \\
\text { 3. To what extent lighting in the work station affect the worker's } \\
\text { productivity? } \\
\text { 4. To what extent does production target pressure affect } \\
\text { worker's productivity? } \\
\text { 5o what extent does the rigidity of regulation affect the workers } \\
\text { productivity? }\end{array}$ \\
\hline $\begin{array}{l}\text { Theoretical } \\
\text { Foundation }\end{array}$ & $\begin{array}{l}\text { 1. Work Stress } \\
\text { a. The Concept of Work Stress } \\
\text { b. Sourches of Work Stress } \\
\text { c. Symptom of Work Stress } \\
\text { Sources : } \\
\text { - Gibson, Ivancevich, Donnelly. 1996. Organisasi, Perilaku, } \\
\text { Struktur, Proses. Jakarta : Bina Rupa Aksara. } \\
\text { - Rice PL. 1992. Stress and Health. California: Brooks. Cole } \\
\text { Publishing Company. } \\
\text { - Robbins, Stephen P. JuDge, Timothy A. 2015. Perilaku Organisasi } \\
\text { (Organizational Behaviour). (Trans.: Ratna Sarawati and } \\
\text { Febriella Sirait). Jakarta: Salemba Empat. } \\
\text { - Related articles terkait local national and International } \\
\text { 2. Productivity } \\
\text { a. Concept of Work Productivity } \\
\text { b. Factors Affecting Work Productivity }\end{array}$ \\
\hline
\end{tabular}


c. Measuring Work Productivity

Sources:

- Hasibuan, S.P. Malayu. 2005. Manajemen Sumber Daya Manusia.

Jakarta: Bumi Aksara.

- Sinungan, MuchDarsyah. 2005. Produktivitas: Aapa Dan

Bagaimana. Jakarta: Bumi Aksara

- Anoraga, Pandji. 2005. Manajemen Bisnis. Cetakan Ketiga

Jakarta: Rineka Cipta.

- Nitisemito, Alex S. 2000. Manajemen Personalia: Manajemen

Sumber Daya Manusia. Third Edition.Jakarta: Ghalia InDonesia.

- Relate articles: local, national, and international

and; (3) functional theory which stresses more on an interaction of effect between the data and theoretical prediction, i.e., the data affect the formation of theory and the formation of theory affects the data. In addition, Sugiyono (2014) explains three functions of a theory, i.e., explanation, prediction and control.

Table 6 below is the example of theoretical foundation which can be used to analyze the topic of the problem related to work stress of production, division, workers.

In a research, especially in writing a research proposal, the presence of theoretical foundation is important, since in its application later the theory is used for various bases of consideration, i.e., (1) as reference in investigation getting a problem, (2) as the basis in formulating research theoretical framework, (3) as the basis in formulating hypothesis, (4) as information for determining the way of testing the hypothesis, and (5) as away of obtaining historical information and perspective of problems to be investigated (Kuntjojo, 2009: 21).

\section{Conclusions and Recommendations}

Research conclusion is a brief statement about the result of analysis and discussion of each problem formulation. In this case conclusion is a brief answer to question asked in problem formulation, so that if there are five problem formulations there will be five conclusions. Conclusions written have to be related to problems and are provided with evidence. According to examples of problem formulation explained in table 3, the conclusions made among others are:

1. A brief explanation about the effect of change of management on worker's productivity.

2. A brief explanation about the effect of worker's family problem on worker's productivity.

3. A brief explanation about the effect of lightening of work station on productivity.

4. A brief explanation about the effect of production target pressure on productivity.

5. A brief explanation about the effect of regulation rigidity on worker's productivity

The purpose of writing conclusion is to provide information to the readers about the content of the research, and to give opportunities to the readers to read quickly the result obtained from the research done.

Final project or minithesis as something that is required from each student at the last semester and which has met certain requirements has to be witten well to produce a certain understanding of phenomenon studied. In this case, the students are expected to understand things studied and be able to solve problems investigated by using an approach which is suitable with the discipline that they have selected as their major. In this paper is explained how to select a topic of research, how to make problem formulation, how to choose theoretical foundation suitable with a topic studied, and appropriate method to be used in solving problems studied, the way how to write a research discussion, and conclusion according to problem formulation that has been written. It is expected that after reading this paper, students can understand the way how to write final project or minithesis in a simple way.

\section{References}

Ary, Donald. Lucy Cheser Jacobs and Asghar Razavieh. 2002. Introduction to Research in Education. Sixth ed. Belmont CA: Wadsworth.

Aswati, F,H. (2014). Hubungan Kecerdasan Emosional dengan Kemampuan Menyelesaikan Skripsi Pada Mahasiswa Program Studi Ilmu Keperawatan Stikes Aisyiyah Yogyakarta. Naskah Publikasi. Program Studi Ilmu Keperawatan Stikes Aisyiyah Yogyakarta. 
Cuervo, Alvaro. Domingo Riberoi. Salvador Roig. 2007. Enterpreneurship: Concepts, Theory and Perspective. Dalam https://www.uv.es/bcjauveg/docs/LibroCuervoRibeiroRoigIntroduction.pdf

Danim, Sudarwan. 2003. Riset Keperawatan Sejarah dan Metodologi. Jakarta: EGC.

Grant, Cyntia and Azadeh Osanloo. 2014. Understanding, Selecting, and Integrating a Theoretical Framework in Dissertation Research: Creating The Blueprint For Your House. Administrative Issue Journal: Connecting Education, Practice, and Research.

Hamidi, 2004. Metode Penelitian Kualitatif: Aplikasi Praktis Pembuatan Proposal Dan Laporan Penelitian. Malang :UMM Press.

Iswahyudi. 2015. Permasalahan Penyusunan Tugas Akhir Mahasiswa Bidang Pengkajian Seni Program Studi Pendidikan Seni Kerajinan Fbs Uny. Jurnal Seni Dan Pendidikan Seni (IMAJI). Volume 13, NomoUD 2, Tahun 2015.

Kuntjojo. 2009. Metode Penelitian. Kediri: Universitas Nusantara PGRI.

Kriyantono, Rachmat.2006. Teknik Praktis Riset Komunikasi.Jakarta: Kencana.

Nasution. 2009. Berbagai Pendekatan Dalam Proses Belajar dan Mengajar. Jakarta: PT Bumi Aksara.

Prajarto, Nunung. 2010. Analisis Isi Metode Penelitian Komunikasi. Yogyakarta: Fisipol Universitas Gajah Mada.

Sugiyono. 2012. Metode Penelitian Kuantitatif Kualitatif dan R\&D. Bandung: Alfabeta.

Sugiyono. 2014. Metode Penelitian Kuantitatif Kualitatif dan R\&D. Bandung: Alfabeta.

Supriyanto, Achmad Sani. Dan Masyhuri Machfudz. 2010. Metodologi Riset: Manajemen Sumberdaya Manusia. Malang: UIN-Maliki Press.

Sukidin. Basrowi. Suranto. 2002. Manajemen Penelitian Tindakan Kelas. Surabaya: Insan Cendekia.

Uhlig, Lauren H. 2012. Choosing a Successful Paper Topic. The Writing Center: Georgetown University Law Center. 